degree of care has been exercised change as aviation progresses. It is to be expected that the safety precautions which courts will require air carriers to take will be steadily increased.

Wilbur J. Russ*

\title{
STANDARDS OF PUNISHMENT IN CONTEMPT CASES
}

Traditionally courts have exercised their power to impose fines and imprisonment for contempt within ill-defined, perhaps arbitrary boundaries. The standards which are available stem from historical common law theories, vague constitutional provisions, and limited statutory enactments. Common law precedents afford little guidance in the way of concrete limits either to trial courts in administering punishment, or to appellate courts in reviewing it.

United States v. Mine Workers ${ }^{1}$ is an outstanding example of the inconclusive results arising from the application of existing standards for determining the extent of punishment. Judge Goldsborough, in the district court, imposed a fine of $\$ 10,000$ on John L. Lewis and a fine of $\$ 3,500,000$ on the union. The United States Suprenie Court voted five to four to modify the judgment by reducing the fine on the union to $\$ 700,000$, with an additional fine of $\$ 2,800,000$ conditioned on continued defiance. The entire court paid lip service to the sanie formulae, yet Justices Rutledge and Murphy dissented, declaring the $\$ 700,000$ fine unconstitutionally excessive. Justices Black and Douglas agreed that the $\$ 700,000$ fine was excessive, but thought a conditional fine of $\$ 3,500,000$ might be reasonable and proper.

The extensive use of contempt proceedings and the perplexing lack of uniformity in result make a careful examination of the existing standards desirable to determine the limits on power to punish, and how these limits are applied in practice.

\section{Types of Contempt}

The limits on punishment vary with the type of contempt involved. Definition of the three major types of contempt proceedings, criminal, coercive civil, and compensatory civil, is necessary since different purposes and rules govern each. Analysis is difficult because a particular contempt may partake of the characteristics of all three. ${ }^{2}$

Criminal contempts are of two distinct types. ${ }^{3}$ Direct contenipts stem

* Member, third-year class.

1330 U.S. 258 (1947).

2 See Bessette v. W. B. Conkey Co., 194 U.S. 324, 329 (1904). Judge Goldsborough is reported to have observed to counsel, "If you know the exact difference between a civil and a criminal contempt, you are the only person who does." N. Y. Times, Nov. 30, 1946, p. 2.

3 Exact definition of the various types of contempt is not undertaken in this note. The leading case is Gompers v. Buck Stove \& Range Co., 221 U.S. 418 (1911). For an excellent discussion of the distinctions between criminal and civil contempt, see Moskovitz, Contempt of Injunctions, Civil and Criminal, 43 Cor. L. REv. 780 (1943). For the history of contempt proceedings, see Comment, 57 Yare L. J. 83 (1947). The difficulty of distinguishing the types of contempt is discussed in Note, 32 VA. L. Rev. 1010 (1946). 
from disrespect in the presence of the court or interference with its ${ }^{\circ}$ proceedings, and are punishable summarily by fine or imprisonment. ${ }^{4}$ Indirect criminal contempts usually result from violation of an order to refrain from acting, or failure to act as ordered, coupled with some element of de-

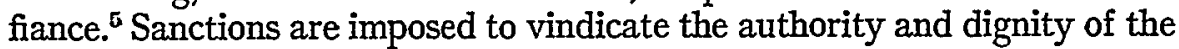
court. ${ }^{6}$ Since past conduct is the basis for punishment, the penalty assessed at the time of sentencing nuust be of a definite term and amount. ${ }^{\top}$

Coercive civil contempt is used to secure compliance with an order or judgnient made for the benefit of the adverse party in a civil action. ${ }^{8}$ Sanctions are imposed only when a party still able to obey refuses or fails to perform an affirmative act as ordered by the court, or persists in violating a continuous negative order. ${ }^{9}$

Compensatory civil contenupt purports to directly conipensate one party for injury resulting from the failure of the opposite party to obey an order. Such proceedings result in a fine being paid to the court for the benefit of the injured party, or occasionally, to that party directly. Many of the formalities and safeguards of a civil action are omitted in this relatively summary procedure. ${ }^{10}$

Since every contempt may contain elenients from each type, violation of an order may be the basis for coercive sanctions to secure future con1pliance, a compensatory fine for injury to the adverse party, and criminal punishment for the past defiance of the court. Of course, there can be no coercive sanctions if the contempt consists only of a past and completed violation of an order to refrain from some act and further violation is no longer possible. ${ }^{11}$

\section{STANDARDS OF PUNISHMENT FOR CRIMINAI CONTEMPT}

Separate standards control punishment under each type of contempt. Punishment for criminal contempt may consist either of a fine payable to the state or imprisonment, or both. ${ }^{12}$

\footnotetext{
4 In re Wilson, 75 Cal. 580, 582, 17 Pac. 698, 700 (1888).

5 Gompers v. Buck Stove \& R. Co., supra note 3 at 441-442.

0 United States v. Mine Workers, supra note I at 302 ; People v. Jersin, 101 Colo. 406, 410, 74 P.2d 668, 670 (1937).

7 Gompers v. Buck Stove \& R. Co., supra note 3 at 443 ; Lopez v. Maes, 38 N.M. 524, 37 P.2d 240 (1934); Ex parte Robertson, 22 Tex. Crim. App. 628, 11 S.W. 669 (1889).

8 United States v. Mme Workers, supra note 1 at 303 ; Gompers v. Buck Stove \& R. Co., supra note 3 at 441 ; United States v. International Union, 190 F.2d 865, 873, 875 (D. C. Cir. 1951).

OGompers v. Buck Stove \& R. Co., supra note 3 at 443; Parker v. United States, 153 F.2d 66 (1st Cir. 1946).

10 United States v. Mine Workers, supra note 1, passim; Gompers v. Buck Stove \& R. Co., supra note 3 , passim; United States v. International Union, supra note 9.

11 "When the court imposes a fine as a penalty, it is punishing yesterday's conteinptuous conduct. When it adds the coercive sanction of imprisonnent, it is announcing the consequences of tomorrow's contumacious conduct." Penfield Co. v. S.E. C., 330 U.S. 585, 594 (1947); United States v. Mine Workers, supra note 1.

12 If the contemnor is an attorney, nany courts hold that he niay be suspended from practice, at least before that court, as an additional sanction. In re Hanson, $134 \mathrm{Kan} .165,5$ P.2d 1088 (1931) (refusal to reinstate attorney suspended in 1916); In re Megill, 114 N. J. Eq. 604, 169 Atl. 501 (Ch. 1933). But cf. Platnauer v. Superior Court, 32 Cal. App. 463, 163 Pac. 237 (1917).
} 
Many states have placed statutory limits on fines and prison terms which may be imposed for contempt. However, if a fine is not paid, the defendant may be committed to jail for an additional period proportional to the size of the fine, even though the total period of imprisonment exceeds the maximum term allowed by statute. ${ }^{13}$

The power to treat contempts as cumulative is widely recognized, and provides an escape route for courts whose powers are strictly limited by statutory ceilings on fines and jail sentences. Each repetition of the act of defiance or day during which it continues can be treated as a separate contempt, pumishable by cumulative fines and consecutive prison terms. Numerous examples may be cited; refusal of a witness to answer a question on two different occasions; ${ }^{14}$ operation of a ferry on successive days in violation of an injunction; ${ }^{15}$ publication of similar contemptuous statements; ${ }^{16}$ broadcasting of contemptuous speeches in different radio broadcasts. ${ }^{17}$

Repetitions are not always treated as separate contempts. Leaving a state and remaining outside to avoid an order was held a single, continuous contempt. The court approved the principle of cumulative punishment, but found it would result in cruel and unusual punishment in the particular case. ${ }^{18}$ Likewise an attorney's repeated interrupting of opposing counsel, despite cautions from the court, has been held a continuous single contempt. ${ }^{19}$

The sanctions applied in criminal contempt cases must be sufficient to adequately pumish the offender, but no more. ${ }^{20}$ To determine what is adequate punishment, the court must consider the extent, the seriousness, and the willfulness of the defiance. ${ }^{21}$ Many factors may be considered in mitigation of the seriousness of the offense. Misconceptions arising from mistake as to existence of the injunction violated, ${ }^{22}$ erroneous advice of counsel, ${ }^{23}$ belief that official duty required the action, ${ }^{24}$ and lack of wrong-

13 In re Victor, 220 Cal. 729, 32 P.2d 608 (1934); Ex parte Karlson, 160 Cal. 378, 117 Pac. 447 (1911); Lay v. District Court, 122 Mont. 61, 198 P.2d 761 (1948).

14 Ex parte Stice, 70 Cal. 51,11 Pac. 459 (1886).

15 Solano Aquatic Club v. Superior Court, 165 Cal. 278, 131 Pac. 874 (1913). But cf. State v. King, 54 La. 701, 17 So. 288 (1895).

16 Lindsley v. Superior Court, 76 Cal. App. 419, 245 Pac. 212 (1926).

17 In re Shuler, 210 Cal. 377, 292 Pac. 481 (1930).

18 Kenimer v. State, 83 Ga. App. 264, 63 S.E.2d 280 (1951). The original judgment was $\$ 11,900$ fine and 1190 days imprisonment. That was reduced to $\$ 4760$ fine and 476 days imprisonment. The reduced fine was held to be unconstitutionally excessive, and the judgment was reversed.

19 State v. Mouser, 208 La. 1093, 24 So.2d 151 (1945).

20 It has been repeatedly said that in contempt proceedings courts should exercise only "the least possible power adequate to the end proposed." Anderson v. Dunn, 6 Wheat. 204, 231 (U.S. 1821); In re Michael, 326 U.S. 224, 227 (1945).

21 Umited States v. Mine Workers, supra note 1 at 303.

22 Merrimack River Sav. Bk. v. Clay Center, 219 U.S. 527 (1911). Other examples of the effect of mistake are found in People v. Jersin, supra note 6 (mistaken behef that acts did not constitute illegal practice of law); United States v. Sullens, 36 F.2d 230 (S.D. Miss. 1929)

(mistaken belief newspaper privileged to publish articles criticizimg and abusing court).

23 Marblchead L. Co. v. Superior Court, 60 Cal. App. 644, 213 Pac. 718 (1923).

24 Des M. Street Ry. Co. v. Des M. Broad-Gauge R. R. Co., 74 Iowa 585, 38 N.W. 496 (1888). 
ful inten $t^{25}$ have all been considered mitigating factors so that only nominal fines were imposed.

In case of direct contempt such factors as sincere apology, ${ }^{26}$ the existence of provocation, ${ }^{2 \tau}$ and subsequent voluntary compliance with an order to answer a question ${ }^{28}$ have all been considered in mitigation. A clean past record may also be considered in reducing the sentence. ${ }^{29}$

Since one purpose of all punishment is to discourage repetitions of the wrongful act by defendant or others, the prophylactic effect of the punishment must be considered by the court. This factor is rarely mentioned in opmions, but no doubt is present in the minds of judges. ${ }^{30}$

A court issumg a judgment for contempt should consider the extent of the defendant's resources and the seriousness to him of the burden of the proposed punishment. ${ }^{31}$ It has been said that a fine so large as to effectively confiscate the estate of the defendant is not necessarily excessive, ${ }^{32}$ but such a fine is certainly suspect.

\section{Non-Statutory Limits on Discretion}

Constitutional prohibitions against cruel and unusual punishments and excessive fines provide the extreme limits to courts' discretionary powers. ${ }^{33}$ Since most reversals rest on the lesser grounds of abuse of discretion, ${ }^{34}$ constitutional restraints are usually expressed negatively, by saying that a particular punishment is not cruel and unusual. However, solitary confinement as punishment for contempt was held unconstitutional, ${ }^{35}$ and a sentence of 476 days in jail and a fine of $\$ 4760$ for leaving a state to avoid obeying a court order was reversed on constitutional grounds. ${ }^{36}$

The test on appeal from a contempt judgment is usually whether or not the trial court acted in an unreasonable, arbitrary, and capricious manner, that is, whether there was abuse of discretion. That test is subjective and

25 Morss v. Doinestic Sewing-Machine Co., 38 Fed. 482 (C. C. Mass. 1889) (violation of patent injunction); People ex rel. Rusch v. Williams, 292 Ill. App. 228, 1 I N.E.2d 37 (1937) (errors in count of ballots due to fatigue); State ex rel. v. Tolls, 160 Ore. 317, 85 P.2d 366 (1938) (county clerk refused to file order, so as to create test case to determine validity of order).

20 United States v. Markewich, 261 Fed. 537 (S.D.N.Y. 1919).

27 Deskins v. State, 62 Okla. Crim. App. 314, 71 P.2d 502 (1937); Rothbard v. Brennan, 263 App. Div. 991, 33 N.Y.S.2d 361 (1942); Matter of Pugh v. Winter, 253 App. Div. 295, 2 N.Y.S.2d 9 (1938).

28 Lockett v. State, 145 Ark. 415, 224 S.W. 952 (1920).

29 Stern v. Rogers, 311 III. App. 654, 37 N.E.2d 568 (1941).

30 Gompers v. Buck Stove \& R. Co., supra note 3 at 443 ; American Zinc Co. v. Vecera, 338 Ill. App. 523, 88 N.E.2d 116 (1949).

31 United States v. Mine Workers, supra note $I$ at 304.

32 In re Megill, supra note 12. In Moore v. United States, 150 F.2d 323 (10th Cir. 1945), a fine which amounted to one-third of the contemnor's assets was upheld, but it was only one-fourth of the permissible fine for the same offense as a crime.

33 U.S. CoNsT. Axrend. VIII and similar provisions in state constitutions.

${ }^{34}$ See, e.g., United States v. Mine Workers, supra note 1.

35 Williams v. State, 125 Ark. 287, 188 S.W. 826 (1916).

36 Kenimer v. State, supra note 18. Compare modern punishments with those described in Davis's Case, 2 Dyer 188 b, 73 Eng. Rep. 415 (K. B. 1560), and accompanying footnotes, which describe the case of a prisoner who threw a brickbat at the judge, narrowly missing him. As punishment, the prisoner's right hand was cut off and fixed to a gibbet, from which he himself was immediately hanged, in the presence of the court. 
uncertain in the extreme. In viewing specific classes of criminal contempt, wide variance can be found in different jurisdictions when the same offense is in issue. A $\$ 50$ fine and ten days imprisonment was held excessive punishment for assault and battery on opposing counsel. ${ }^{3 r}$ Another court held reasonable a fine of $\$ 1000$ for attacking a witness, ${ }^{38}$ while yet another held that a fine of $\$ 100$ and temporary suspension of an attorney from practice was a proper penalty for assaulting a juror. ${ }^{39}$

For statements reflecting on the honesty and integrity of courts, punishments of 120 days imprisonment, ${ }^{40}$ a $\$ 5000$ fine and one year imprisonment, ${ }^{41}$ a $\$ 250$ fine and suspension from the practice of law for a period of one year, ${ }^{42}$ and a $\$ 200$ fine have been assessed..$^{43}$ Improperly approaching a judge with intent to influence his decision was held insufficient to justify a $\$ 100$ fine and three hours imprisonment, since the only possible purpose of the imprisonment would be to embarrass the defendant. ${ }^{44}$

Serious perjury brought a sixty day committal in one court, ${ }^{45}$ but another punished an unimportant perjury resulting from misinterpretation of a question with a $\$ 500$ fine and thirty days imprisonment. ${ }^{46}$

For attempting to bribe jurors, punishments of $\$ 250$ fine, ${ }^{47}$ six months imprisonment, ${ }^{48}$ thirty months imprisonment, ${ }^{49}$ and a $\$ 5000$ fine have all been sustained. ${ }^{50}$ Violations of injunctions forbidding picketing have resulted in a sentence of four months imprisonment in one case, ${ }^{, 61}$ and fine of $\$ 1000$ against the union and $\$ 100$ against each picket in another case in the same jurisdiction. ${ }^{.2}$

Although courts discuss the factors and attempt to apply the standards under discussion here, the cases show remarkable lack of uniformity of result.

\section{Statutory Limits on Discretion}

Many legislatures have attempted to standardize punishment for criminal contempt by placing statutory limits on the extent of punishment. Such restrictions are usually held constitutional if they do not so greatly limit

3r Pace v. State, 177 Ark. 512, 7 S.W.2d 29 (1928).

35 Brannon v. Commonwealth, $162 \mathrm{Ky} .350,172$ S.W. 703 (1915).

39 Tanner v. United States, 62 F.2d 601 (10th Cir. 1932).

40 Ex parte John D. Crews, 127 Fla. 381, 173 So. 275 (1937) (representing that he could influence the court).

41 State ex rel. v. Davenport, 125 Okla. 1, 256 Pac. 340 (1927) (filing motion charging supreme court with wrongful acts).

42 In re Glauberman, 107 N. J. Eq. 384, 152 Atl. 650 (Err. \& App. 1930) (filing bricf impugning motives to trial court).

43 In re Friday, 138 Cal. App. 660, 32 P.2d 1117 (1934) (filing bill of exceptions charging judge with improperly consultimg opposing counsel).

44 Freedman v. State, 176 Md. 511, 6 A.2d 249 (1939).

45 In re Caruba, 140 N. J. Eq. 563, 55 A.2d 289 (Err. \& App. 1947).

46 United States v. Lampkin, 66 Fed. Supp. 821 (S.D. Fla. 1946).

47 McCauley v. State, 124 Neb. 102, 245 N.W. 269 (1932).

48 Tasich v. State, 111 Neb. 465, 196 N.W.688 (1923).

49 Dolan v. Commonwealth, 304 Mass. 325, 23 N.E.2d 904 (1939).

50 French v. Commonwealth, 30 Ky. Law Rep. 98,97 S.W. 427 (1906).

51 Hake v. The People, 230 MI. 174, 82 N.E. 561 (1907).

52 American Zimc Co. v. Vecera, supra note 30. 
the power of courts to punish as to destroy the effectiveness of their contempt jurisdiction. ${ }^{53}$

The federal courts are governed in part by statute and in part by common law. Statutes provide that indirect contempts which are also crimes under state or federal law and are not violations of an order or judgment in an action brought by the federal government may be punished by fine or imprisonment, but the imprisonment is limited to six months, and in the case of a natural person, the portion of the fine payable to the government must not exceed $\$ 1000 .^{54}$

Common law rules still govern all contempts committed in the presence of the court or so near as to interfere with the administration of justice, all contempts consisting of violations of orders or decrees in actions brought by the United States, and all contempts not otherwise crimes under state or federal law. ${ }^{55}$ This is limited by the fact that punishment must consist of either fine or imprisonment, but not both for the same offense. ${ }^{56}$

The provisions of the California codes are fairly typical of the statutory restrictions on sentences for criminal contempt. California imposes an absolute ceiling of $\$ 500$ on fines and five days on jail sentences in the case of judgments of contempt rendered by superior courts and $\$ 100$ and one day on judgments of inferior courts. ${ }^{57}$ The fines, if not paid, can be satisfied by imprisonment at the rate of $\$ 2.00$ per day. ${ }^{58}$

In many states an act punished as a contempt may also be punished as a crime. 59 The constitutional inhibitions on double jeopardy are not violated by this practice, because two separate causes of action arise, one for the act against the court's digmity, and the other for the breach of public peace. ${ }^{\circ 0}$

53 Opinion of the Justices, 86 N.H. 597, 166 Atl. 640 (1933) (advising that proposed statute would be unconstitutional) ; Spight v. State, 155 Ark. 26, 243 S.W. 860 (1922) (statute unconstitutional); see People v. White, 334 Ill. 465, 484, 166 N.E. 100, 107 (1929); Crook v. Schumann, 292 Ky. 750, 756, 167 S.W.2d 836, 840 (1942). But cf. In re Garner, I79 Cal. 409, 177 Pac. 162 (1918) ; State v. Baker, 222 Iowa 903, 270 N.W. 359 (1936) (statutes held constitutional).

54 28 U.S.C. $\$ \$ 386,387$ (1946).

5528 U.S.C. \$ 389 (1946), after listing certain types of cases, continues " . . . and all other cases of contenipt not specifically enibraced within section 386 of this title, may be punished in conformity to the usages at law and in equity prevailing on October 15, 1914." (The date the section was enacted.)

5028 U.S.C. $\$ 385$ (1946).

57 Car. Code Crv. Proc. \$ 1218. Held constitutional, In re Garner, supra note 53. A fine of $\$ 1000$ is provided in CAL. COdE Crv. Proc. $\$ 1097$ as punishment for failure to obey a writ of mandate or prohibition.

5 Cal. Pen. Code $\$ 1205$.

69 Cal. PeN. Code \$§ 166, 657, 658. Flannagan v. Jepson, 177 Iowa 393, 158 N.W. 641 (1916).

Co In re Morris, 194 Cal. 63, 227 Pac. 914 (1924). Justice Rutledge, in his dissenting opinion in United States v. Mine Workers, supra note 1 at $377-378$, suggests that when an act is both a crime and a contenipt, the punishnient prescribed by statute for the crinie should also be the maxinium punishment that could be iniposed for the contempt. There is a dictum to the effect that the criminal punishment should be considered carefully in weighing the reasonableness of a contempt judginent in Ryals v. United States, 69 F.2d 946, 948 (5th Cir. 1934). Most cases hold, however, that the punishment for contempt can greatly exceed the punishment for the same act as a crime. United States v. Lederer, 140 F.2d 136 (7th Cir. 1944); Hake v. The People, supra note 51; State v. Davenport, supra note 41. 


\section{STANDARDS OF PUNISHMENT FOR COERCIVE CIVIL CONTEMPT}

The rules governing coercive sanctions applied in civil contempt cases are far different from those applied in criminal cases. The punishment may consist of a fine payable to the state, or occasionally to the other party, if the defendant does not comply with the orders of the court before a certain day, ${ }^{61}$ or imprisonment until he performs, ${ }^{62}$ or both. ${ }^{63}$

The cardinal principle of coercive sanctions is that punishment is conditioned on continued defiance. Imprisonment must cease on compliance with the court's orders. The exact extent of pumishment depends on defendant himself. Because he "carries the keys to his prison," ance releasing him, a defiant attitude may keep him in prison indefinitely. ${ }^{\text {or }}$

Since defendant can avoid paying any fine.at all, the fine imposed on condition of his continued disobedience can be far greater than would be tolerable as a punitive fine assessed after the event. ${ }^{66}$

Constitutional provisions forbidding imprisonment for debt are said to apply to coercive sanctions. If the defendant is unable to pay a money judgment or deliver a fund of money which he has never had, he camiot be imprisoned. The act to be performed must be within the defendant's power unless he has willfully incapacitated himself from performing. ${ }^{67}$ However, imprisonment to enforce an order for payment of money is not unconstitutional if the defendant is able to pay. ${ }^{68}$ The English Debtors Act specifically provides for one year incarceration for failure to pay a sum of money. 60

61 United States v. Mine Workers, supra note 1; London Guarantee \& Accident Co. v. Doyle \& Doak, 134 Fed. 125 (C.C.E.D.Pa. 1905).

${ }_{62}$ CAL. CODE Crv. Proc. \$1219 provides, "When the contempt consists in the omission to perform an act which is yet in the power of the person to perform, he may be imprisoned until he have performed it ...." Similar provisions exist in many states and in the common law. In re Salkin, 5 Cal. App. 2d 436, 42 P.2d 1041 (1935); State ex rel. Enochs v. Dist. Court, 113 Mont. 227, 123 P.2d 971 (1942); Ex parte Julius Klugsberg, 126 Tex. 225, 87 S.W. 2d 465 (1935); In re Stewart, 121 Wash. 429, 209 Pac. 849 (1922); all holding that a person may be imprisoned under a coercive contempt judgment for a longer time than he could be for criminal contempt.

${ }^{63}$ As an additional means of coercion, it is frequently held that a court can refuse to allow a person to prosecute an action while he is in contempt of court. None of the contemnor's motions will be granted, and if he is the plaintiff, he need not be allowed to appeal. MacPherson v. MacPherson, 13 Cal. 2d 271, 89 P.2d 382 (1939) (appeal denied); O'Neill v. Thomas Day Co., 152 Cal. 357, 362, 92 Pac. 856, 859 (1907) (dictum that complaint can be struck); Monterey Coal Co. v. Superior Court, 11 Cal. App. 207, 104 Pac. 585 (1909) (change of venue denied). Courts do not bave the power to deny a defendant the right to defend an action and appeal from an adverse judgment. Hovey v. Elliot, 167 U.S. 409 (1897); Foley v. Foley, 120 Cal. 33, 52 Pac. 122 (1898); McHan v. McHan, 59 Idaho 41, 80 P.2d 29 (1938).

64 In re Nevitt, 117 Fed. 448, 461 (8th Cir. 1902).

65 For an example of a person who was in jail for five years and out on bail for another five years, see Tegtmeyer v. Tegtmeyer, $292 \mathrm{Ml}$. App. 434, 11 N.E. $2 \mathrm{~d} 657$ (1937), af'd, $306 \mathrm{Ill}$. App. 169, 28 N.E. 2d 303 (1940), rev'd in part, 314 III. App. 16, 40 N.E. 2d 767 (1942).

66 United States v. Mine Workers, supra note 1.

67 People v. LaMothe, 331 Ill. 351, 163 N.E. 6 (1928) ; Lopez v. Maes, supra note 7; see Ex parte Joutsen, 154 Cal. 540, 545, 98 Pac. 391, 393 (1908). But cf. Cox v. Rice, 375 Ill. 357,31 N.E. 2 d 786 (1940) (trustee could be imprisoned for failure to pay over fund he had wrongfully disposed of).

68 Carnahan v. Carnahan, 143 Mich. 390, 107 N.W. 73 (1906); Campbell v. Motion Picture M. Operators, 151 Minn. 238, 186 N.W. 787 (1922).

6932 \& 33 VICT. c. $62, \$ 4$ (1869); 41 \& 42 VICT. c. 54 (1878). 
In general the limiting factor on coercive punishment is that while it must be sufficiently stringent to produce compliance with court orders, it should not be greater than absolutely necessary. ${ }^{70}$ As a preliminary to imposing any sanctions, the court must consider the seriousness of the defendant's behavior, the amount of harm likely to result from it, and the importance of terminating the behavior and discouraging repetition. ${ }^{71}$ Even such a subjective factor as the personality of the defendant merits consideration, for observation reveals that some men seek martyrdom, while others quail at the least suggestion of force. ${ }^{22}$

The court must also consider the extent of the defendant's resources and the prospective gain or loss from continuation of the contempt. A sanction that would produce instant compliance from a poor farmer resisting a foreclosure would hardly daunt a great corporation seeking illicit profits, ${ }^{73}$ or the United Mine Workers demanding a new wage increase. ${ }^{T 4}$

The possible effect of the sanction on the contemnor's ability to perform is a matter of great importance. A large fine for failure to pay alimony might incapacitate the defendant from paying. Of course, if the fine were made payable to the recipient of the alimony no harm would be done, since it would be but a different means of exacting payment. Likewise, in the same type of case, a jail sentence would defeat the purpose of the court by preventing the offendor from earning money with which to make the required payments.

Some states, like California, have no provision for conditional fines. However, since each day defiance continues may be a separate offense, the threat of future criminal proceedings for continued contumacy can be effectively used to secure compliance.

It is worthy of note that in California coercive contempt jurisdiction must be exercised if necessary to secure the rights of a litigant. Mandamus will issue from an appellate court to force a trial court to apply its contempt powers for the benefit of a party to an action. ${ }^{75}$

\section{STANDARDS OF PUNISHMENT FOR COMPENSATORY CIVIL CONTEMPT}

Civil contempt proceedings are also used directly to recompense a party to an action. The fine is ordinarily payable to the court for the benefit of the injured party, or, in some states, directly to the party himself. ${ }^{78}$

The compensatory fine should be equal in amount to the actual damages proved, ${ }^{7 T}$ most states adding costs and attorney fees. ${ }^{78}$ New York has

To Supre note 20.

71 United States v. Mine Workers, supra note 1 at $304,335$.

72 In re Nevitt, supra note 64.

73 See In re Millington, 24 Kan. 214 (1880).

Tu United States v. Mine Workers, supre note 1.

75 Crocker v. Conrey, 140 Cal. 213, 73 Pac. 1006 (1903).

70 Supra note 10.

77 Campbell v. Motion Picture M. Operators, supra note 68; Guerrier v. Coleman, 135 App. Div, 46, 119 N.Y. Supp. 895 (1909). Damages are ordinarily measured by amount of injury to the coinplainant, Parker v. United States, 126 F.2d 370 (1st Cir. 1942), but in some cases, such as violations of court orders regarding patents, damages are considered to be the profits made by the contemnor. Leman v. Krentler-Arnold Co., 284 U.S. 448 (1932).

78 Morehouse v. Giant Powder Co., 206 Fed. 24 (9th Cir. 1913); Trotcky v. Van Sickle, 
an unusual statute providing for a $\$ 250$ fine plus costs and fees if no greater damages are established. ${ }^{70}$

Since great injury is possible, a large fine may result, as the examples following demonstrate. A gravel company was fined $\$ 1500$ for discharging hydraulic tailings in violation of an injunction. ${ }^{80} \mathrm{~A} \$ 5000$ fine for perjury was imposed when false testimony prevented the complainant from collecting a lawful debt of that amount. ${ }^{81}$. Another person was fined $\$ 3050$ for disobeying a court order to turn an insurance fund of that amount over to a receiver. ${ }^{82} \mathrm{~A}$ fine of $\$ 250,642$ was assessed against a mining company that undermined city streets in violation of an injunction. ${ }^{83}$

Paynent of the compensatory fine can be enforced by committal in most states, and, like the coercive sanction, the committal is usually not a violation of the provisions forbidding imprisonment for debt if defendant is able to pay. ${ }^{84}$

California has no provision for compensatory contempt proceedings. Civil damages may be collected in an ordinary civil action for an act otherwise a contempt.

\section{APPELLATE REVIEW}

Standards of punishment are of little value without some means of insuring their proper application. At common law appeal existed only in civil contempt cases. ${ }^{85}$ In England, even today, there is no appeal from criminal contempt judgments rendered by the English High Court of Justice. ${ }^{80}$ Most American jurisdictions have developed some type of review. Appeal is provided by statute in some jurisdictions. ${ }^{87}$ Others, including the federal, examine the extent of punishment by certiorari..$^{88}$

There is no appeal as such from a contempt judgment in California, ${ }^{80}$ but review is available by habeas corpus proceedings or by certiorari. ${ }^{00}$ Under those proceedings, the appellate court will inquire only into the jurisdiction of the trial court. If jurisdiction existed and was not exceeded, the judgment must be affirmed. ${ }^{01}$ Apparently when contempt is governed

227 Ind. 441, 85 N.E. 2d 638 (1949) ; Foreman v. Foreman, 111 Utah 72, 176 P. 2d 144 (1946).

79 N. Y. Judiciary Law, Art. 19, § 773, 29 McKinnex's Consor. Laws (1948); Geller Flamount Realty Corp., 260 N.Y. 346, 183 N.E. 520 (1932).

80 In re North Bloomfield Gravel Min. Co., 27 Fed. 795 (C.C.D. Cal. 1886).

81 Malmud v. Blackman, 177 Misc. 162, 30 N.T.S.2d 174 (Sup. Ct. 1941).

82 Mendelsohn v. Rosenberg, 248 App. Div. 743, 288 N.X.Supp. 792 (1936).

83 Scranton v. Peoples Coal Co., 274 Pa. 63, 117 Atl. 673 (1922).

${ }_{84}^{84}$ Supra notes 67 and 68.

85 Oswald, ContendPT OF Court 229 et. seq. (3d ed. 1910).

86 Supreme Court of Judicature Act, 1873, 36 \& 37 VIcr. c. 66, $\S \S 19,47 ; 8$ Halsburx's LAWS OF ENGLAND, Contempt, $\S \S 3,35,48$ (2d ed. 1932 ).

87 Dangel, Contentr 284 (1939).

88 United States v. Mine Workers, supra note 1.

89 "The judgment and orders of the court, judge, or justice, made in cases of contempt, are final and conclusive." CaL. Code Crv. Proc. \$ 1222 ; Gale v. Tuolumne County Water Co., 169 Cal. 46, 145 Pac. 532 (1914).

00 The scope of review in habeas corpus and certiorari is said to be identical. It re Lake, 65 Cal. App. 420, 423, 224 Pac. 126, 127 (1924). For a discussion of the scope of review of contempt judgments in California, see Comment, 36 CaLIF. L. REv. 75, 98 (1948); Note, 37 Carte. L. Rev. $301^{\prime}$ (1949).

91 Meyberg v. Superior Court, 19 Cal.2d 336, 121 P.2d 685 (1942); Bridges v. Superior 
by statutory limits no punishment within the prescribed bounds will be considered in excess of jurisdiction, for it has been said that within those limits the appellate court will not inquire into the reasonableness of the punishment. $^{92}$

\section{CONCLUSIONS AND RECOMMENDATIONS}

It would be difficult, if not impossible, to establish a universal formula by which to prescribe punishment for contempt. Sanctions nuust be sufficiently flexible to punish all types of offenses and to produce compliance with any type of order. They must also be tailored to fit the particular contempt and contemnor, in view of all the facts in each case.

The need for flexibility suggests that courts should be given wide discretionary powers. However, individual liberty must be protected from arbitrary and capricious acts. To gain this end, California limits judicial discretion by statute. The federal courts review it on certiorari. It is difficult to say which technique has produced the best results. The permissible penalties in Califorma occasionally may be inadequate. On the other hand, appellate review is not the path to certainty, as was demonstrated by the Mine Workers case.

The greatest stumbling block seenis to be the fact that "contempt" encompasses such a multitude of sins. One possible, although partial, solution to the problem of finding adequate standards for the pumshment of contempt is categorization of offenses. This technique has been helpful in criminal law. No reason appears why it could not be applied to contempt. A careful statutory classification of offenses should be made. Appropriately stringent maximum penalties could be prescribed for each type of offense. In that way the danger of unlimited judicial discretion would be avoided, yet heavy penalties could be imposed for serious contempts.

\section{Thomas C. Ackerman, Jr.*}

Court, 14 Cal.2d 464, 94 P.2d 983 (1939), rev'd on other grounds, 314 U.S. 252 (1941); Tripp v. Tripp, 190 Cal. 201, 211 Pac. 225 (1922); People v. Latimer, 160 Cal. 716, 117 Pac. 1051 (1911); White v. Superior Court, 110 Cal. 60, 42 Pac. 480 (1895).

92 In re Carboni, 46 Cal. App. 2d 605, 116 P.2d 453 (1941); In re Friday, supra note 43; Lindsley v. Superior Court, supra note 16.

* Meunber, second-year class. 